\title{
BOTANICAL SAMPLING GAPS ACROSS THE CAMEROON MOUNTAINS
}

\author{
Moses Nsanyi Sainge ${ }^{1,2}$, Jean-Michel Onana ${ }^{3,4}$, Felix NChu ${ }^{5}$, David Kenfack ${ }^{6}$ and A. \\ TOWNSEND PETERSON ${ }^{7}$ \\ ${ }^{1}$ Tropical Plant Exploration Group (TroPEG), P.O. Box 18, Mundemba, Ndian, South West \\ Region, Cameroon; ${ }^{2}$ Department of Environmental and Occupational Studies, Faculty of Applied \\ Sciences, Cape Peninsula University of Technology, Cape Town Campus, Keizersgracht, P.O. \\ Box 652, Cape Town 8000, South Africa: ${ }^{3}$ National Herbarium of Cameroon. P.O. Box 1601 \\ Yaoundé, Centre Region, Cameroon; ${ }^{4}$ Department of Plant Biology, Faculty of Science, \\ University of Yaoundé 1. P.O. Box 812 Yaoundé, Cameroon; ${ }^{5}$ Department of Horticultural \\ Sciences, Faculty of Applied Sciences, Cape Peninsula University of Technology, P.O Box 1906, \\ Bellville 7535, South Africa; ${ }^{6}$ Center for Tropical Forest Science, Smithsonian Institution Global \\ Earth Observatory, Washington, DC 20560-0166 USA ${ }^{7}$ Biodiversity Institute, University of
} Kansas, 1345 Jayhawk Blvd., Lawrence, Kansas 66045 USA

\begin{abstract}
With the emergence of a new field, biodiversity informatics, an important task has been to evaluate completeness of biodiversity information that is existing and available for various countries and regions. This paper offers a first and very basic assessment of sampling gaps and inventory completeness across the Cameroon Mountains. Because digital accessible knowledge is severely limited for the region, we relied on qualitative evaluations of inventory completeness, supplemented by large amounts of data from the National Herbarium of Cameroon (YA) database. Detailed botanical inventories have been developed for Mt Cameroon, the Kupe-Mwanenguba Mountains, Mt Oku, and the Mambila Plateau, leaving substantial geographic and environmental coverage gaps corresponding to Rumpi Hills, Mt Nlonako, Kimbi Fungom National Park, Bali and Bafut Ngemba, Mt Bamboutos, Kagwene, and Tchabal Mbabo. This paper provides a roadmap for a comprehensive botanical survey for this region. Completing this survey plan, the resulting data will allow researchers to track changes in biodiversity and identify priority areas for conservation on the various mountain ranges that make up this important biodiversity hotspot.
\end{abstract}

Keywords.- biodiversity informatics, primary biodiversity data, sampling gaps, inventory completeness, mountains.

The Cameroon Mountains, also known as the Cameroon Line (Nono et al. 2004) or Cameroon Volcanic Line (Ayonghe et al. 1999, Marzoli et al. 2000), comprise a chain of isolated volcanic and plutonic mountain peaks that covers $\sim 40,877 \mathrm{~km}^{2}$, stretching from Pagalu Island in the Gulf of Guinea to the Mandara Mountains in the interior. The oceanic portion of the mountain chain covers $\sim 2998 \mathrm{~km}^{2}$ in the form of 4 major islands (Pagalu, $17 \mathrm{~km}^{2}$; São Tomé, $854 \mathrm{~km}^{2}$; Principe, $110 \mathrm{~km}^{2}$; Bioko, $2017 \mathrm{~km}^{2}$; Ayonghe et al. 1999, Frodin 2001). The continental portion of the mountain chain is broader, covering $\sim 37,879 \mathrm{~km}^{2}$, extending from Mt Cameroon $(4095 \mathrm{~m})$ and Mt Etinde (commonly called Small Mt Cameroon, $1474 \mathrm{~m}$ ) on the coast, through a string of peaks, extending to the north and east into the interior (Figure 1).
The largest part of the Cameroon Mountain chain lies within Cameroon, which is the focus of this study, but it extends into adjacent Nigeria at sites including the Mambila Plateau, Obudu Plateau, Mbola Hills, Mt Shebsi, and the Biu Plateau (Hepper 1965, 1966, Hall and Medler 1975, Ayonghe et al. 1999; Figure 1).

Numerous protected areas cover at least some portions of the Cameroon Mountain chain, including Mt Cameroon National Park, Bakossi National Park, Santchou Forest Reserve, KimbiFungom National Park, Mbam et Djerem National Park, and Vallée de la Mbéré National Park. However, although endemism is high in the region overall, particularly for plants, these protected areas were established based on minimal information, and no quantitative conservation 


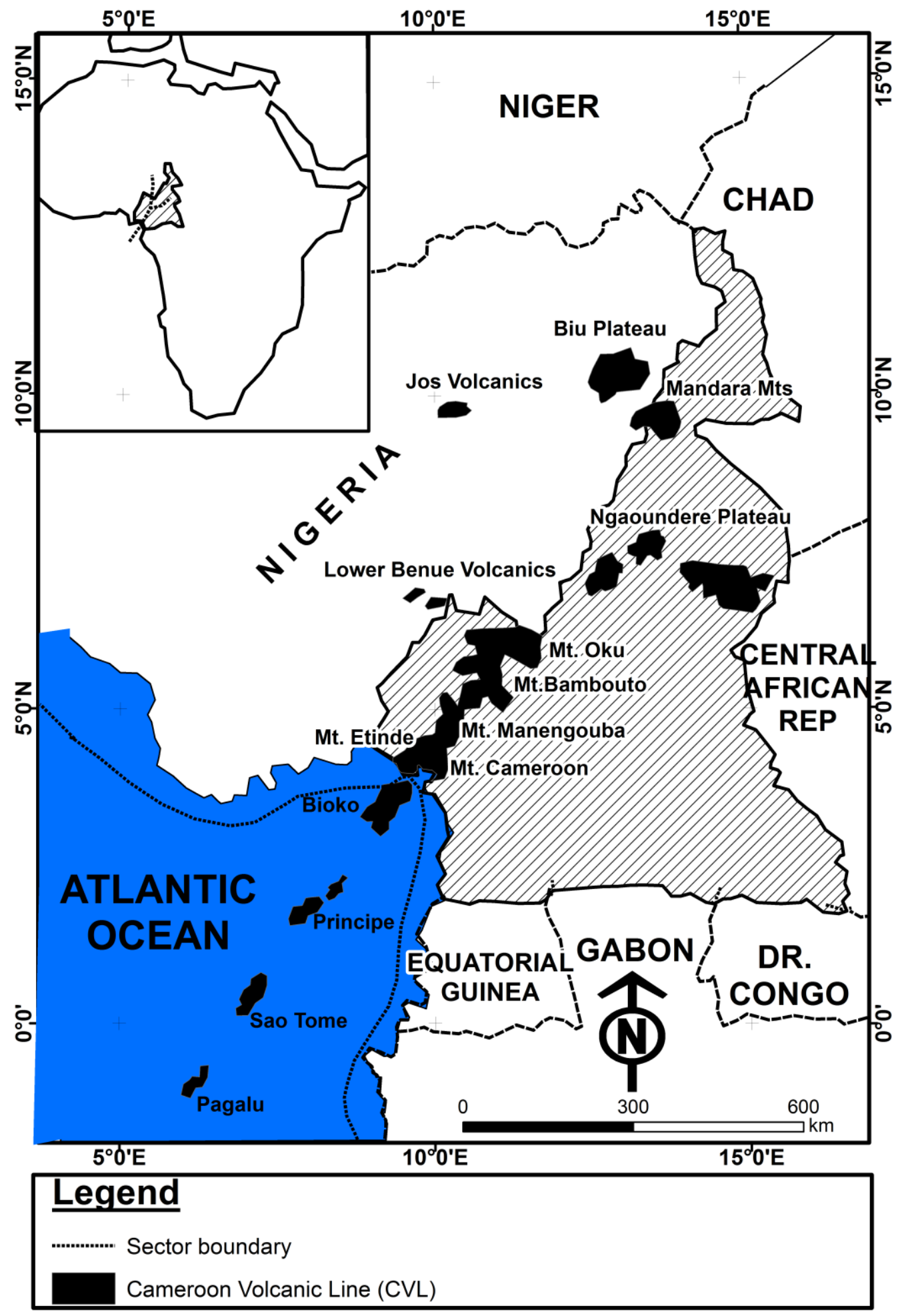

Figure 1. Diagrammatic representation of the Cameroon Mountain chain, extending from islands in the Gulf of Guinea to the coastal Mt Cameroon, and inland along the Cameroon-Nigeria border. 
prioritization has been developed for the region. Botanists have invested considerable energy in basic surveys of the plants of this region, although few primary data are available openly from this work. Reasonably complete botanical surveys have been developed for only a few sites: this study set out to characterize those points of light and the intervening gaps in detail.

More generally, however, the Cameroon Mountains hold tropical montane forests known internationally for their rich floras and high levels of endemism, combined with high degrees of threat (Myers et al. 2000, Onana and Cheek 2011). This biome is part of a mega-hotspot of Western Africa cited as having impressive species diversity and hosting numerous endemic taxa (Mittermeier et al. 1999, Myers et al. 2000, Marchese 2015). Still, only scanty primary biodiversity data are available for the region, and-to our knowledge-no quantitative analysis of conservation priority has been developed regarding any taxon for the region. As such, a detailed evaluation of gaps in knowledge regarding the biota of this region is presented here to lay a foundation for more detailed inventories and analyses in terms of structure and composition, species diversity, and richness. Because major sectors of the botanical knowledge of this region remain in non-digital or non-shared formats, our analyses are necessarily qualitative at this point, in hope of transition to fully digital and quantitative in coming years.

\section{METHODS}

We focused on montane areas with elevations $>1600 \mathrm{~m}$, but we considered information from those areas down to $600-1000 \mathrm{~m}$. We produced a spatial dataset summarizing the distribution of montane areas within the Cameroon Mountains from the GMTED2010 digital elevation model $\left(\mathrm{DEM}^{1}\right)$, at a spatial resolution of 7.5" ( 230 $\mathrm{m}$ at the Equator). We reclassified the raw DEM into elevational intervals of $0-1000 \mathrm{~m}$ (lowlands), 1000-1600 m (foothills), and $>1600 \mathrm{~m}$ (montane areas), and created vector-format shape-files of areas $>1000 \mathrm{~m}$ and $>1600 \mathrm{~m}$ to facilitate analyses. Finally, for analysis, we further subdivided two large areas into smaller subunits based on relatively low valleys that were nonetheless above $1600 \mathrm{~m}$ (Figure 2).

\footnotetext{
${ }^{1}$ http://topotools.cr.usgs.gov/gmted viewer/.
}

Primary data on previous botanical surveys across the region were derived from published documents, floras, monographs, reports, and the databases of the National Herbarium of Cameroon (YA) (Holmgren et al. 1990). From the latter source, 23,667 records were assessed for accuracy, and records falling in highland areas extracted. This information was summarized in spreadsheets that included latitude, longitude, elevation, number of data records, and number of species documented, but numbers of records and species were unconvincingly low; the bulk of existing information for the plants of the region remains in non-digital formats. As a consequence, we resorted to a qualitative evaluation (our consensus opinion) of completeness of the inventory of each area, as 0 $=$ never (to our knowledge) visited, $1=$ incidental data, 2 = some records, and $3=$ a published 'flora' or otherwise comprehensive summary that appears to be reasonably complete; we focused on areas with completeness at only the latter level, which we considered, at least in a preliminary sense, as well-sampled.

Once we had established which polygons could be considered as well-sampled, we converted the shapefile to raster (geotiff) format using custom scripts in R (R Foundation for Statistical Computing 2004). This raster coverage was the basis for our identification of gaps, as follows. We used the proximity (raster distance) function in QGIS (version 2.4) to summarize geographic distances from all montane sites to those that are well-sampled. To create a parallel view of environmental difference from well-sampled areas, we plotted 5000 random points across the Cameroon Mountains (i.e., in areas $>1600 \mathrm{~m}$ ), and used the point sampling tool in QGIS to link each point to the geographic distance raster, and to raster data layers at $30 "(\sim 1 \mathrm{~km})$ spatial resolution summarizing annual mean temperature and annual precipitation from the WorldClim climate data archive (Hijmans et al. 2005). We first rescaled values of each environmental variable to the overall range of the variable as $\left(x_{i}-x_{\min }\right) /\left(x_{\max }-\right.$ $x_{\text {min }}$ ), where $x_{i}$ is the particular observed value in question, such that each environmental variable varied only $0-1$. We calculated the minimum Euclidean distance in the two-dimensional climate space to any well-sampled area (Sousa-Baena et al. 2014). Finally, these environmental distances were 
SAinge ET AL. - CAmeroon Mountains Plants

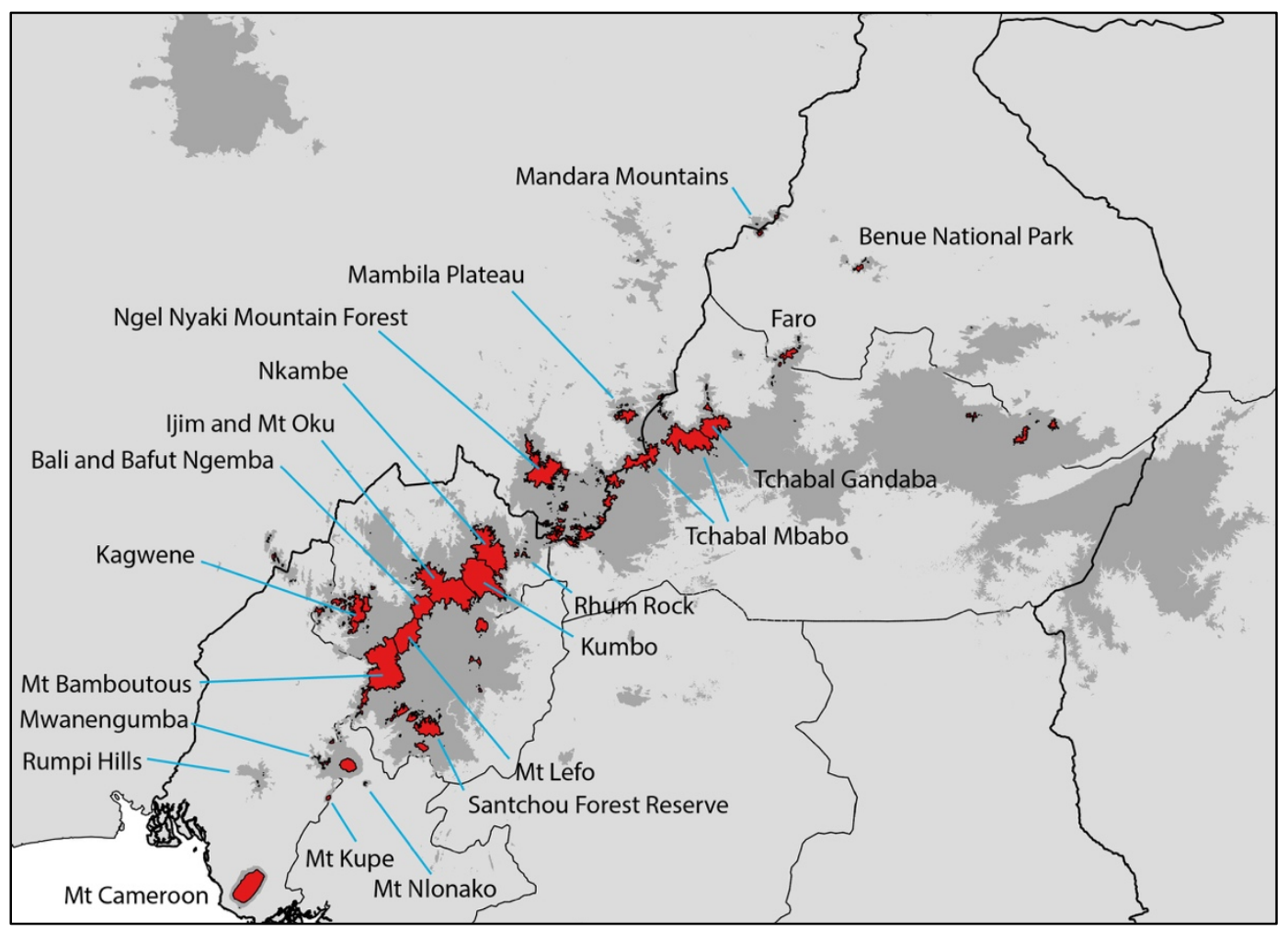

Figure 2. Summary of highland areas in the continental portion of the Cameroon Mountains region. Areas above $1000 \mathrm{~m}$ elevation are shown in darker gray shading. Areas above $1600 \mathrm{~m}$ are shown colored red and outlined in black. The more important such highland areas are labeled for reference to the text.

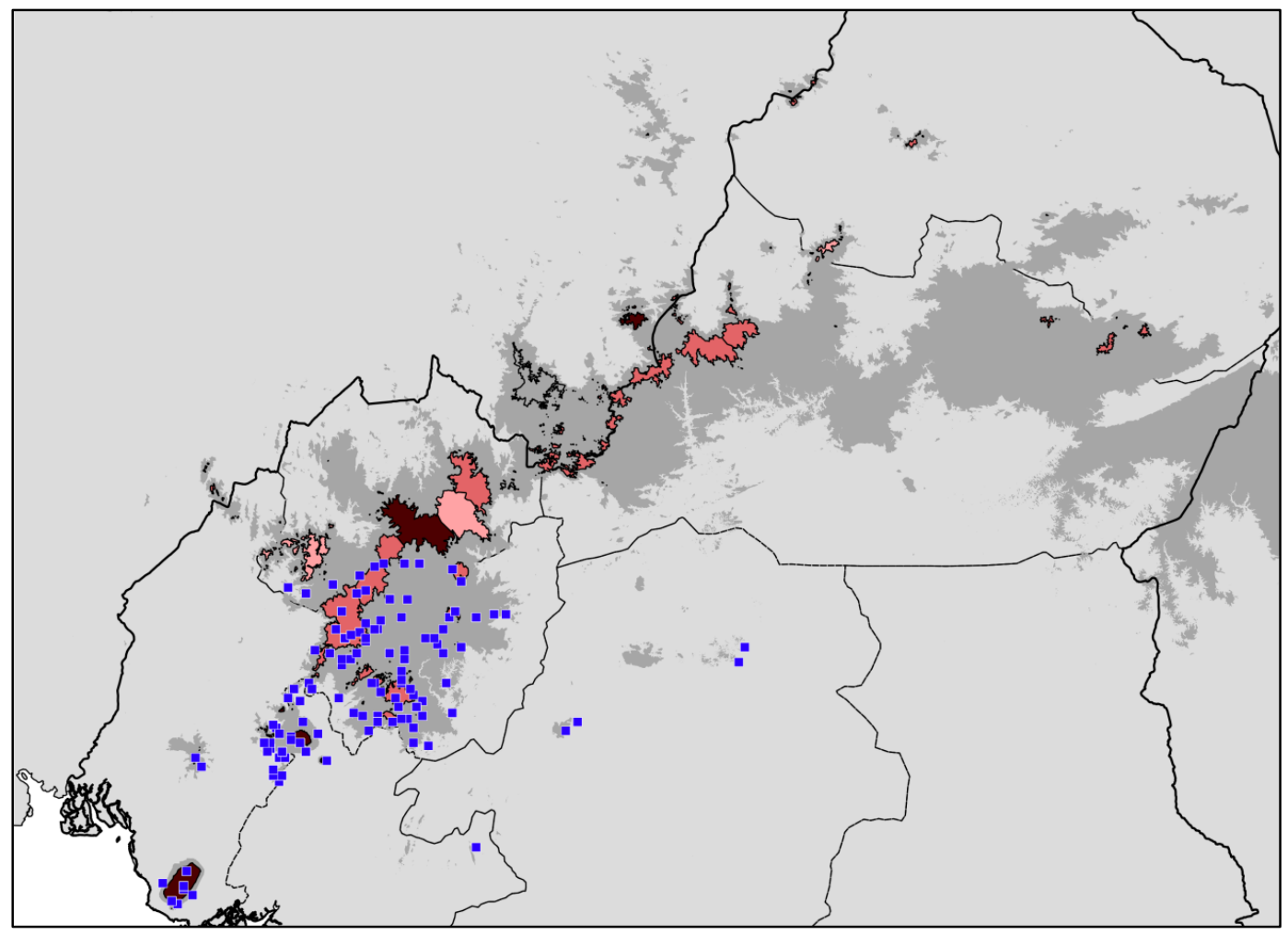

Figure 3. Map of the continental portion of the Cameroon Mountains region, showing points sampled in the YA collections in blue. The different highland areas are indicated as well-sampled (dark red), some sampling (medium red), some information (light red) or no information (gray). 
imported into QGIS, and linked back to the random point shape-file.

\section{RESULTS}

Among the 23,667 digital herbarium records from YA, 13,609 records corresponded to highlands within the Cameroon Mountains region, the latter data representing a total of 3995 species (Figure 3). Data derived from published papers, reports, floras, and monographs correspond to 3314 records of 1175 species in the Cameroon Mountains region. Our analysis shows significant sampling gaps along this mountain chain, including the Rumpi Hills, Mt Nlonako, the Lebialem Highlands west of Mt Bamboutos, and the Bamenda Highlands (extending to Tchabal Mbabo and the Adamawa Plateau). Our explorations of the YA database (Figure 3) indicated that data were sparse for individual montane areas, preventing quantitative analysis (Colwell and Coddington 1994). As a result, we were forced to rely on our qualitative analysis, detailed below.

A broad view of the Cameroon Mountains region with our qualitative inventory summary is presented in figures 1 and 2 . We identified 3 highland sites that could be considered as wellinventoried: Mt Cameroon, Mt Mwanenguba (including Bakossi National Park), and the Mambila Plateau. Sites for which at least some information exists include Santchou Forest Reserve, Mt Bamboutous, Mt Lefo, Bali and Bafut Ngemba Forest Reserve, Ijim and Mt Oku, Tchabal Mbabo, Tchabal Gandaba, Mandara Mountains, and Benue National Park. Other areas, however, are characterized by only scanty botanical information (e.g., Mt Nlonako, Kagwene, Rhum Rock, Faro Reserve). For 3 sites, we could find no indication of any previous botanical work: Nkambe, Rhum Rock, Ngel Nyaki Mountain Forest. See Table 1 for a summary of all of this information.

Geographically, the sites most distant from well-known sites were the Adamawa Plateau and Tchabal Mbabo (Figure 2). Interestingly, in terms of environmental distances, the sites most different from well-known sites were quite different from the list based on geographic distances. Specifically, the montane areas most distinct in terms of environments were the Rumpi Hills, Mt Nlonako, as well as the Lebialem Highlands west of Mt
Bamboutos. These sites are curiously located more or less centrally in the Cameroon Mountains chain, and are geographically relatively close to wellknown sites (Figure 4, Table 1).

\section{DISCUSSION}

The continental part of the Cameroon Mountains with focus on Cameroon is one of the most diverse sites in Africa, and has been classified as a biodiversity hotspot (Cheek et al. 2000, Cheek et al. 2004, Barthlott et al. 2005). This region is the only part of Central Africa with an elevational range from sea level to $>4000 \mathrm{~m}$, and holds a high diversity of plants $>6000$ species out of the $\sim 9000$ species so far known to occur in Cameroon (Cable and Cheek 1998, Cheek et al. 2000, Cheek et al. 2004, Onana and Cheek 2011, Onana 2011). At the continental level, this region has great affinity in species composition with other montane sites such as the mountains of West Africa (e.g., Bersama abyssinica; Cheek et al. 2004) and East Africa (e.g., Polyscias fulva, Strombosia scheffleri, Schlefflera abyssinica, Alangium chinense, Maesa lanceolata; DowsettLemaire 1989, Thomas and Thomas 1996; Cheek et al. 2000, Cheek et al. 2004, Sainge 2016).

This region holds $>200$ species of plants that are considered as threatened, which is the highest in Cameroon and perhaps the highest in west and Central Africa (Cheek et al. 2004, Onana and Cheek 2011), with $>80$ species endemic (Cheek et al. 2004, Franke 2004, Sainge et al. 2005, Sainge et al. 2010, Sainge 2012, Sainge 2016). Examples of threatened and endemic plant species occurring in the region are Afrothismia saingei, A. fungiformis, Rhaptopetalium geophylax, Schefflera manni, Syzyzium staudtii, Ixora foliosa, Gambeya korupensis, Deinbollia angustifolia, and Begonia pseudoviola. The region hosts 3 of the 7 genera endemic to Cameroon (Hamilcoa, Medusandra, Platytinospora); finally, the only endemic family in Cameroon (Medusandraceae) is represented here, with its two species: Medusandra mpomiana and M. richardsiana (Cheek et al. 2004, Onana 2013).

However well, this landscape has been visited by and sampled by botanists, although that work was mostly in terms of surveys of species' occurrences; most of the data remain in nondigitized formats. This information thus remains inaccessible to scientists with interest on African 


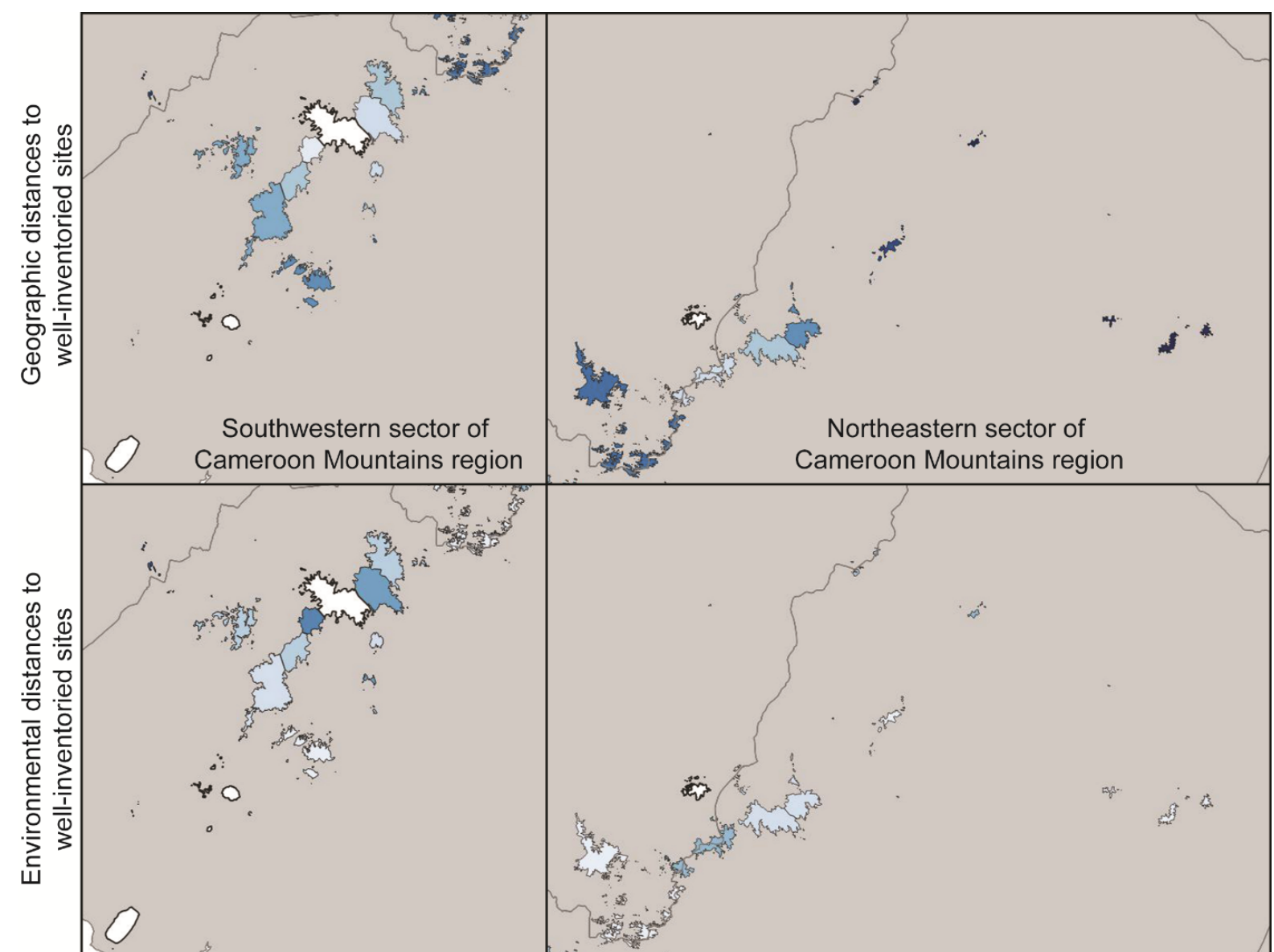

Figure 4. Summary of gaps in coverage in terms of inventories of plants in the Cameroon Mountains region. White indicates well-known sites; darker shades of blue indicate greater distance (geographic space) or difference (environmental space) from well-surveyed sites. Left-hand column is the southwestern part of the chain; right-hand column is the northeastern part of the chain.

Table 1. Highland areas in the continental portion of the Cameroon Mountains region with focus in Cameroon. Areas are presented roughly in order from southwest (Mt. Cameroon) to northwest.

\begin{tabular}{lccccc}
\hline Montane unit & $\begin{array}{c}\text { Number of species } \\
\text { recorded }\end{array}$ & Latitude & Longitude & $\begin{array}{c}\text { Elevation } \\
(\mathrm{m})\end{array}$ & $\begin{array}{c}\text { Degree of } \\
\text { documentation }\end{array}$ \\
\hline Mt Cameroon & 2435 & 4.2833 & 9.2167 & 2600 & 3 \\
Rumpi Hills & 326 & 4.8886 & 9.2418 & 1749 & 1 \\
Mt Kupe & 10 & 4.7921 & 9.6779 & 966 & 1 \\
Mwanengumba (incl. Bakossi NP) & 2412 & 4.9969 & 9.8564 & 2040 & 3 \\
Mt Nlonako & 351 & 4.9031 & 9.9578 & 1606 & 1 \\
Santchou Forest Reserve & 134 & 5.2602 & 10.0470 & 801 & 2 \\
Mt. Bamboutous (incl. Lebialem Highlands) & 222 & 5.6008 & 10.0400 & 2176 & 2 \\
Mt Lefo & 95 & 5.8641 & 10.3453 & 1239 & 2 \\
Kagwene & 70 & 6.2717 & 9.4338 & 1025 & 1 \\
Bali and Bafut Ngemba Forest Reserve & 415 & 5.8291 & 10.1026 & 1615 & 2 \\
Ijim and Mt Oku & 920 & 6.1146 & 10.2856 & 2200 & 1650 \\
Kumbo & 1 & 6.2032 & 10.6848 & 1650 & 1 \\
Nkambe & 0 & 6.6101 & 10.6707 & 1572 & 0 \\
Rhum Rock & 0 & 6.4671 & 11.0387 & 1603 & 0 \\
Ngel Nyaki Mountain Forest & 0 & 7.0903 & 11.0667 & 1167 & 0 \\
Tchabal Mbabo & 215 & 7.2406 & 12.1458 & 2166 & 2 \\
Mambila Plateau (incl. Gashaka Gumti NP) & 213 & 7.3838 & 11.7303 & 1140 & 3 \\
Tchabal Gandaba & 155 & 7.0911 & 14.4376 & 1013 & 1021 \\
Faro Reserve & 17 & 7.7151 & 12.4251 & 1021 \\
Mandara Mountains & 518 & 10.4942 & 13.6359 & 1079 \\
Benue National Park & 309 & 8.0405 & 14.0066 & 851 & 1 \\
\hline
\end{tabular}


biodiversity, particularly those based in Africa. We attempted to develop quantitative views of botanical inventory completeness across the Cameroon Mountains region (after Sousa-Baena et al. 2014, Idohou et al. 2015, Kouao et al. 2015), but we were stymied by the small numbers of primary occurrence data that are available for the region. As a consequence, in our second effort, we used a literature review to detect and identify landmark studies that have documented Cameroon Mountain sites in good detail, but found little or no access to the primary data that underlay those publications and that document the individual specimens collected. The occurrence data points from the Cameroonian National Herbarium corroborated this view: good numbers of occurrence points concentrated in sites identified as well-sampled in the qualitative analysis.

In sum, then, the online digital accessible knowledge (DAK; Sousa-Baena et al. 2014) for Cameroon remains entirely too sparse, and should be the focus of intensive data development efforts. With a conservative estimate of $\sim 155,000$ specimens (and likely many more) collected to date in the country (Onana 2011), only $\sim 65,000$ $(41.9 \%)$ are represented in the database of YA (J.M. Onana, unpubl. data.). This gap exists because large-scale collections made from the colonial era into the 1950s and subsequent decades are deposited in major herbaria in Europe and North America; although not without exceptions, most of these data remain undigitized and largely inaccessible to the broader community interested in African biodiversity. Although some of the big data-holders have begun steps to make information available (Le Bras et al. 2017), the DAK impediment thus remains significant, with much of the primary data from extensive botanical surveys in the country remaining offline. This blockage of information flow must be resolved if any quantitative analyses of biodiversity pattern, subregional endemism, and conservation priority are to be developed for the region.

\section{ACKNOWLEDGMENTS}

We thank JRS Biodiversity Foundation for funding training activities that led to this collaboration. This paper is a contribution of Tropical Plant Exploration Group (TroPEG), Cameroon.

\section{LiTERATURE CITED}

Ayonghe, S. N., G. T. Mafany, E. Ntasin, and P. Samalang. 1999. Seismically activated swarm of landslides, tension cracks, and a rockfall after heavy rainfall in Bafaka, Cameroon. Natural Hazards 19:13-27.

Barthlott, W., J. Mutke, D. Rafiqpoor, G. Kier, and H. Kreft. 2005. Global centers of vascular plant diversity. Nova Acta Leopoldina 92:61-83.

Cable, S., and M. Cheek. 1998. The Plants of Mount Cameroon: A Conservation Checklist. Royal Botanic Gardens, Kew, United Kingdom.

Cheek, M., J. M. Onana, and B. J. Pollard. 2000. The Plants of Mount Oku and the Ijim Ridge, Cameroon. Royal Botanic Garden, Kew, United Kingdom.

Cheek, M., B. J. Pollard, L. Darbyshire, J. M. Onana, and C. Wild. 2004. The Plants of Kupe, Mwanenguba, and the Bakossi Mountains, Cameroon: A Conservation Checklist. Royal Botanic Garden, Kew, United Kingdom.

Colwell, R. K. and J. A. Coddington. 1994. Estimating terrestrial biodiversity through extrapolation. Philosophical Transactions of the Royal Society of London B 335:101-118.

Dowsett-Lemaire F. 1989. The flora and phytogeography of the evergreen forests of Malawi. 1: Afromontane and mid-altitude forest. Journal of the National Botanical Garden, Belgium 59:3-131

Franke T. 2004. Afrothismia saingei (Burmanniaceae), a new myco-heterotrophic plant from Cameroon. Systematics and Geography of Plants 74:27-33.

Frodin, D. G. 2001. Guide to the Standard Floras of the World, 2nd ed. Cambridge University Press.

Hall, J. B., and J. A. Medler. 1975. The botanical exploration of the Obudu Plateau area. Nigeria Field 40:101-117.

Hepper, F. N. 1965. The vegetation and floral of the Vogel Peak massif of the northern Nigeria. Bulletin of the Institut Fondamental d'Afrique Noire, Series A. 27:413-513.

Hepper, F.N. 1966. Outline to the vegetation and flora of the Mambila Plateau, northern Nigeria. Bulletin of the Institut Fondamental d'Afrique Noire, series A. 28:91-127.

Hijmans, R.J., S. E. Cameron, J. L. Parra, P. G. Jones, and A. Jarvis. 2005. Very high resolution interpolated climate surfaces for global land areas. International Journal of Climatology 25:1965-1978.

Holmgren, P.K., N. H. Holmgren, and L. C. Barnett. 1990. Index Herbariorum, $8^{\text {th }}$ ed. New York Botanical Garden, New York.

Idohou, R., A. Ariño, A. Assogbadjo, R.G. Kakai, and B. Sinsin. 2015. Diversity of wild palms (Arecaceae) in the Republic of Benin: Finding the gaps in the national inventory combining field and digital 
accessible knowledge. Biodiversity Informatics 10:45-55.

Kouao, J.K., A.F. Kouassi, C.Y. Adouyao, A. Bakayoko, I. Josephipou, J. Bogaert. 2015. The present state of botanical knowledge in Côte d'Ivoire. Biodiversity Informatics 10:56-64.

Le Bras, G. L., M. Pignal, M. L. Jeanson, S. Muller, C. Aupic, B. Carré, G. Flament, M. Gaudeul, C. Gonçalves, V. R. Invernón, F. Jabbour, E. Lerat, P. P. Lowry, B. Offroy, E. P. Pimparé, O. Poncy, G. Rouhan, and T. Haevermans. 2017. The French Muséum National d'Histoire Naturelle vascular plant herbarium collection dataset. Scientific Data 4:170016.

Marchese, C. 2015. Biodiversity hotspots: A shortcut for a more complicated concept. Global Ecology and Conservation 3:297-309.

Marzoli, A., E. M. Piccirillo, P. R. Renne, G. Bellieni, M. Iacumin, J. B. Nyobe, and A. T. Tongwa. 2000. The Cameroon Volcanic Line revisited: Petrogenesis of continental basaltic magmas from lithospheric and asthenospheric mantle sources. Journal of Petrology 41:87-109.

Mittermeier, R. A., N. Myers, C. G. Mittermeier, and P. Robles-Gil. 1999. Hotspots: Earth's Biologically Richest and Most Endangered Terrestrial Ecoregions. CEMEX, SA, Agrupación Sierra Madre, Mexico City, Science.

Myers, N., R.A. Mittermeier, C.G. Mittermeier, G.A.B. da Fonseca, and J. Kent. 2000. Biodiversity hotspots for conservation priorities. Nature 403:853-858.

Nono, A., E. Njonfang, A. K. Dongmo, D. G. Nkouathio, and F. M. Tchoua. 2004. Pyroclastic deposits of the Bambouto volcano (Cameroon Line, Central Africa): Evidence of an initial strombolian phase. Journal of African Earth Sciences 39:409414.

Onana, J. M. 2011. The Vascular Plants of Cameroon. A Taxonomic Check List with IUCN Assessements.
Flore du Cameroun 39. IRAD-National Herbarium of Cameroon, Yaoundé.

Onana, J. M., and M. Cheek. 2011. The Red Data Book of the Flowering Plants of Cameroon. Royal Botanic Garden, Kew, United Kingdom.

Onana J.M. 2013. Synopsis des espèces végétales vasculaires endémiques et rares du Cameroun. Check-liste pour la conservation de la biodiversité. In J. M. Onana (ed.). Flore du Cameroun 40, Ministry of Scientific Research and Innovation (MINRESI), Yaoundé.

R Foundation for Statistical Computing. 2004. R, version 3.1.2. https://www.r-project.org/.

Sainge, M.N., T. Franke, and R. Agerer. 2005. Afrothismia korupensis (Burmanniaceae, tribe Thismieae) from Korup National Park, Cameroon. Wildenowia 35:287-291.

Sainge, M.N., T. Franke, V. Merckx, and J.-M. Onana. 2010. Distribution of myco-heterotrophic (saprophytic) plants of Cameroon. In: X. van der Burgt, J. van der Maesen \& J.-M. Onana (eds), Systematics and conservation of African plants, Royal Botanic Gardens, Kew. pp. 279-286.

Sainge M.N. 2012. Systematics and Ecology of Thismiaceae of Cameroon, Master of Science Thesis, University of Buea, Cameroon. 110 pp.

Sainge, N.M. 2016. Patterns of distribution and Endemism of Plants in the Cameroon Mountains: A case study of Protected Areas in Cameroon: Rumpi Hills Forest Reserve (RHFR) and the Kimbi Fungom National Park (KFNP). Tropical Plant Exploration Group (TroPEG), Buea, Cameroon.

Sousa-Baena, M.S., L. C. Garcia, A. T. Peterson. 2014. Completeness of digital accessible knowledge of the plants of Brazil and priorities for survey and inventory. Diversity and Distributions 20:369-381.

Thomas, D.W., and J. Thomas. 1996, Tchabal Mbabo Botanical Survey. World Wide Fund for Nature (WWF). Yaounde, Cameroon. 